\title{
Human Interference and Deterioration of the Character of Wetlands: A Micro level Study in Labpur Block, Birbhum District, West Bengal
}

\author{
Niladri Das \\ Research Scholar, Department of Geography, Visva-Bharati, West Bengal, India
}

\begin{abstract}
The term 'wetland' is used broadly and covers a wide range of environmental units including swamps, bogs, salt marshes, lakes and some river edges. Wetlands have simultaneously been described as the "Kidneys of Landscape" and as "Biological Supermarkets" because they act as stock of natural resources, have potential to provide diverse flows of various socio-economic services. But unfortunately, countrywise wetland loss over the last 150 years is calculated at a staggering $90 \%$ due human need and greed. Labpur block in Birbhum district is a wetland dominated block. About $12.64 \%$ area out of total block area is under wetlands. There are 10 major seasonal and permanent wetlands located in a scattered manner, among them Langolhata beel is largest wetland. But recently all the wetlands are facing serious problems regarding their existence. Increase of population pressure with the excessive economic use of wetlands push them into the way of deterioration. This paper aims to extract the major problems associated with the economic and unscientific use of wetlands in the study area.
\end{abstract}

Key words: Barrage Construction, Embankment construction, Ground water draft, Irrigation, Road construction

\section{INTRODUCTION}

Wetlands are lands transitional between terrestrial and aquatic systems where the water table is usually at or near the surface or the land is covered by shallow water [1]. They are one of the important sources of natural resources, upon which rural economy depends [2]. With the ample supply of water, wetlands can provide large number of ecological and hydrological supports such as retention of nutrients, flood control, ground water recharge and provide habitat to a number of species [3]. According to the data of NWTS (National Wetland Trend Study) $8 \%$ of fresh water wetlands of the world have lost their identities due to extension of agricultural land during mid-1950 to 1970 [4]. Moreover in most countries these ecosystems were unfortunately destructed by human interferences which resulted in considerable loss of wetlands in all over the world [5]. In the study area wetlands are belonging to the category of floodplain wetlands and they are well connected with the perennial and non-perennial channels. So, the river regulation has resulted in major changes to the inundation regime of the flood plain wetlands [6]. Even slight changes in hydrology may result in significant alteration of the wetlands' hydrological processes [7]. In the present era huge population pressure in the Labpur block allows unscientific economic use of wetlands and its associated rivers. As a result indigenous hydrological characteristics of wetlands become deteriorated and have adverse impact on surface and subsurface hydrological regime of both wetlands and associated rivers. So, this paper involves finding out the major human interferences toward the wetlands and their associated problems and finally formulating some probable remedial strategies for development of wetlands in the study area.

\section{STUDY AREA}

Labpur C.D block is one of the largest C.D. Blocks of Birbhum district West Bengal, India, spanning $267.35 \mathrm{Km}^{2}$. This block includes 11 Gram Panchayats with 180 mauzas. The block is located between $23^{\circ} 42^{\prime} 44^{\prime \prime} \mathrm{N}$ and $23^{\mathrm{O}} 53^{\prime} 46^{\prime \prime} \mathrm{N}$ latitudes and between $87^{\circ} 43^{\prime} 06^{\prime \prime} \mathrm{E}$ and $87^{\mathrm{O}} 58^{\prime} 02^{\prime \prime} \mathrm{E}$ longitudes. In the study area 10 major seasonal and permanent wetlands are located in a scattered manner and cover 33.77 ha which accounts for $12.64 \%$ area out of total block area. Locally the wetlands are termed as beel area. So, in the present study report this term has been used as synonymous with wetland. 


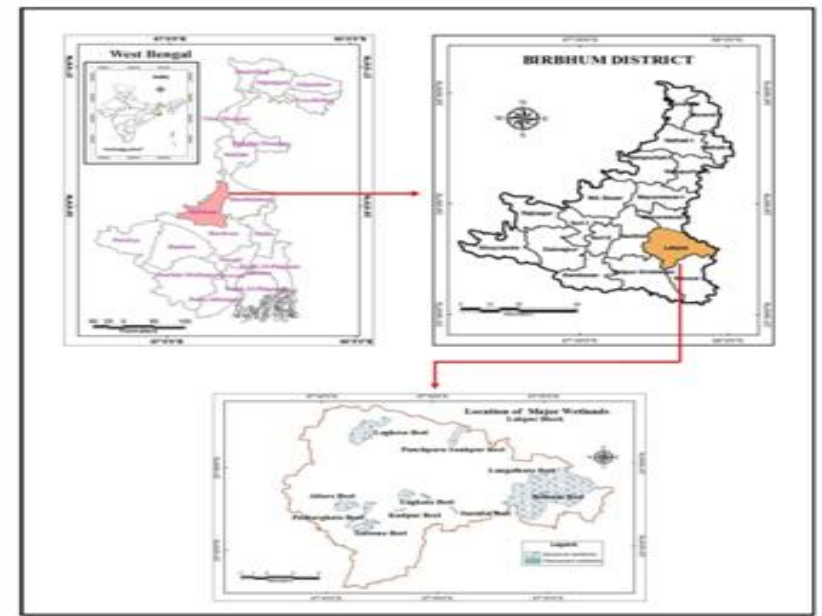

Figure 1: Location of the Study Area

\section{MATERIALS AND METHODS}

Toposheet of Survey of India of 1921-22 and 1970-71 and satellite imagery of 2013 and 2014 and Google Earth of 2015 have been consulted to prepare different kinds of human interference through maps. Empirical survey has been conducted to collect ground water draft data, ground water level data in different periods, crop damage data, settlement shifting data etc. Different official data have been taken into consideration for previous ground water level data, irrigation data, dam related data etc.

\section{IV.}

\section{RESULT AND ANALYSIS}

\subsection{Effect of Embankment Construction}

Regulation of river can change the hydrophytic character of an aquatic ecosystem [8]. There is direct relation between river discharge and the behaviour of hydrological regime of floodplain wetlands. There are several overflow points through which wetlands are recharged during monsoon season when the river discharge is at peak level. But the construction of embankment has restricted such direct flow. Fig.2 depicts the regulated flow of Kuya river, passing through Langolhata beel, by constructing embankment. Before the construction of the embankment, the discharge of the Kuya river helped for recharging the water level of the Langolhata beel and waterlogged condition remained over this part. But after the construction of embankment in 2007, Kuya river has lost its overflowing links along the left bank. As a result now the northern part of the Langolhata beel has completely dried up with few depressed waterlogged area during monsoon only. Embankment construction between beel area and river has an adverse impact on hydric soil character of wetland. Table 1 shows some changes in the behaviour of soil properties between two sides of the beel areas like soil moisture and soil organic matter. The southern part of the river, where linkage prevails between Langolhata beel and the river Kuya, has maintained the characteristics of hydric soil in terms of moisture. The moisture in this part during pre-monsoon season is $17.57 \%$ and the availability of the humus or organic carbon is about $2.18 \%$. But in the opposite side of the embankment it is noticed that the amount of soil moisture during pre-monsoon as well as organic carbon become lowered down because the northern part of the Langolhata beel is used for intensive agricultural practice with updrafting of ground water even during monsoon season.

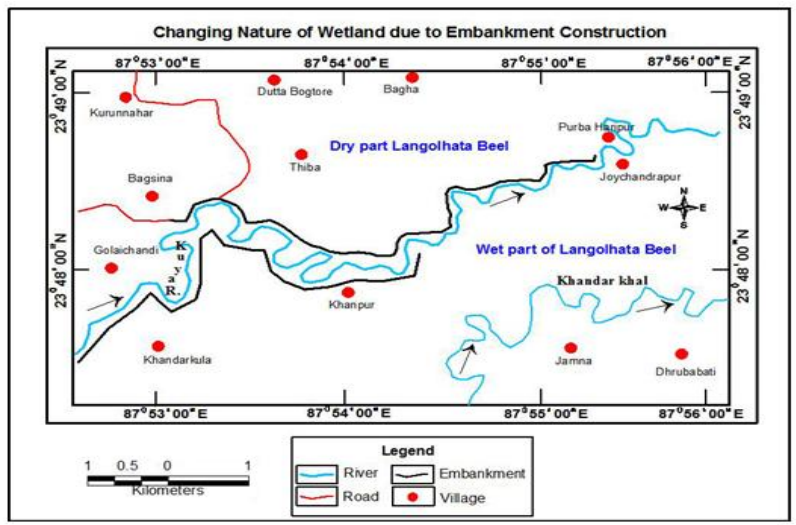

Figure 2: Effect of Embankment Construction 
Table 1 : Changing Characteristics of Wetland's Soil due to Construction of Embankment

\begin{tabular}{|c|c|c|c|c|c|}
\hline \multicolumn{2}{|c|}{$\begin{array}{c}\text { Southern part of the } \\
\text { embankment }\end{array}$} & \multicolumn{2}{c|}{$\begin{array}{c}\text { Northern part of the } \\
\text { embankment }\end{array}$} & \multicolumn{2}{c|}{ Differences } \\
\hline $\begin{array}{c}\text { Soil moisture } \\
\text { (Pre-monsoon) }\end{array}$ & $\begin{array}{c}\text { Organic } \\
\text { carbon }\end{array}$ & $\begin{array}{c}\text { Soil moisture } \\
\text { (Pre- } \\
\text { monsoon) }\end{array}$ & $\begin{array}{c}\text { Organic } \\
\text { Carbon }\end{array}$ & $\begin{array}{c}\text { Soil moisture } \\
\text { (Pre- } \\
\text { monsoon) }\end{array}$ & $\begin{array}{c}\text { Organic } \\
\text { Carbon }\end{array}$ \\
\hline $17.57 \%$ & $2.18 \%$ & $10.21 \%$ & $1.21 \%$ & 7.36 & 0.97 \\
\hline
\end{tabular}

Source: Laboratory Analysis

\subsection{Conversion of Wetland to Agricultural Land}

According to the data of NWTS (National Wetland Trend Study) $8 \%$ of fresh water wetlands of the world have lost their identities due to extension of agricultural land during mid 1950 to 1970 [4].

There are two means of wetland conversion to agricultural land: one is direct conversion by draining and clearing of wetlands for the purpose of agricultural extension and another one is indirect conversion which is related with normal agricultural activity which is going on in the wetland area [4] .Table 2 reveals almost all the beel areas have changed into permanent agricultural field between 1921-22 to 2013-14. A large scale conversion can be noticed in Langolhata beel, about $57 \%$ land is converted into permanent agricultural land. Both Babna and Rajarampur beel are totally converted into agricultural field at present. There is no seasonal waterlogged condition except extreme monsoon season. Another large scale conversion has been noticed in Patharghata, Altore, Talbona and Laghosa beel. Table 3 shows the conversion of Surulia beel into agricultural land within 42 years. There is about 3 hectares of area of this permanent beel which is now used for cultivation.

Table 2: Conversion of Different Beel Area into Agricultural Land

\begin{tabular}{|c|c|c|c|}
\hline \multirow[b]{2}{*}{ Name of the beel } & \multicolumn{2}{|c|}{ Beel area in hectare } & \multirow{2}{*}{$\begin{array}{c}\text { Conversion to Agricultural } \\
\text { land (hectare) }\end{array}$} \\
\hline & 1921-22 & 2013-14 & \\
\hline Langolhata Beel & 2232 & 947 & 1285 \\
\hline Laghata Beel & 144 & 116 & 28 \\
\hline $\begin{array}{l}\text { Pathargha and Altore } \\
\text { Beel }\end{array}$ & 537 & 298 & 239 \\
\hline Talbona Beel & 252 & 54 & 198 \\
\hline Babna Beel & 19 & 0 & 19 \\
\hline Rajarampur Beel & 99 & 0 & 99 \\
\hline Panchpara Beel & 131 & 78 & 53 \\
\hline Laghosa Beel & 524 & 174 & 350 \\
\hline
\end{tabular}

Source: Toposheet 1921-22, Liss-III Imagery 2013 and Field Check

Table 3: Conversion of Surulia Beel into Agricultural Land

\begin{tabular}{|c|c|c|}
\hline Year & Area in Hectare & $\begin{array}{l}\text { Conversion of wetland to agricultural land } \\
\text { (Hectare) }\end{array}$ \\
\hline 1971 & 8 & \multirow{2}{*}{$\mathbf{3}$} \\
\hline 2013 & 5 & \\
\hline
\end{tabular}

Source: SOI Toposheeet, 1971 and LISS-III Imagery, 2013 and Field Check

This kind of conversion disrupt major ecological and as well as hydrological exchanges [9]. With this conversion the beel area are being squeezed and has lost its water holding capacity, and consequently, severe flood occurs during monsoon season. This kind of changing nature of flood of the beel area not only change the inundation character of beel but also people of this region face a huge loss from crop damages. The loss of crop production per hectare of each beel area has been estimated on the basis of its average yield (Table 4) 
Table 4: Loss of Crops/ Hectare

\begin{tabular}{|l|c|c|c|}
\hline \multirow{2}{*}{ Name of the beel } & Avg. Yield/ha & During extreme monsoon & Normal monsoon \\
\cline { 3 - 4 } & 4665 & 9.77 & 5.05 \\
\hline Langolhata & 4976 & 1.97 & 0.94 \\
\hline Laghosa & 4043 & 1.29 & 0.82 \\
\hline Patharghata & 4976 & 0.94 & 0.22 \\
\hline Panchpara & 4043 & 0.55 & 0.31 \\
\hline Altore & 3421 & 0.41 & 0.17 \\
\hline Talbona & 3421 & 0.33 & 0.14 \\
\hline Laghata & Soure: ADO & & \\
\hline
\end{tabular}

Source: ADO Office, Labpur and Field work

\subsection{Construction of Road through Beel Area}

Road construction through the beel area is another sign of human intervention. In the beel area of Langolhata numbers of roads have been constructed to make connection with surrounding villages (Fig 3). But this kind of manmade construction leads to blockage in the water flow and results in subsequent flooding [10]. Metalled roads have been constructed through Sankpur-Panchpara beel and Altore-Patherghata beel which also causes increase of flood height due to blockage of water flow during monsoon. Flood water also damages the roads during monsoon season every year (Fig. 4 and 5). Therefore, a lumpsum monetary investment is expended every year after monsoon for repairing.

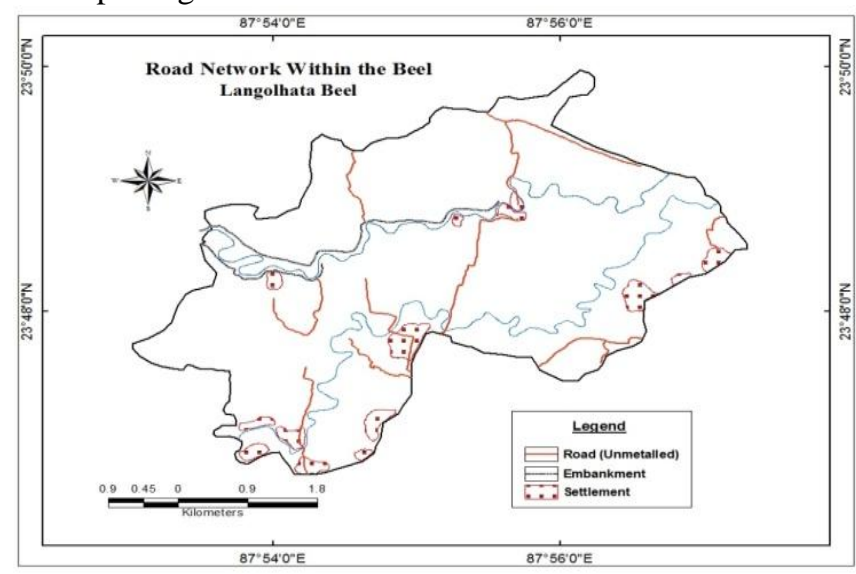

Source: Google earth, 2015

Figure 3: Construction of Roads within Langolhata beel

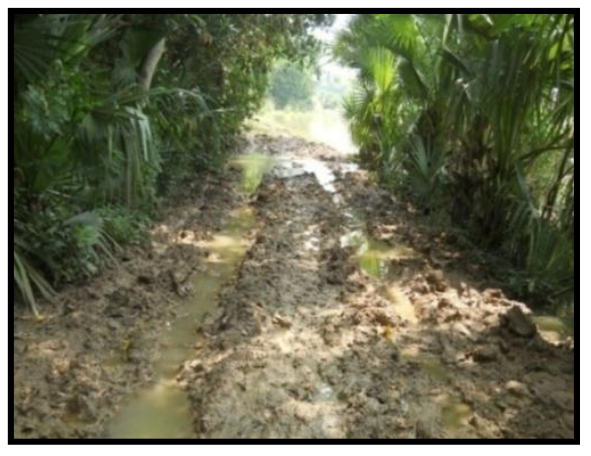

Figure 4

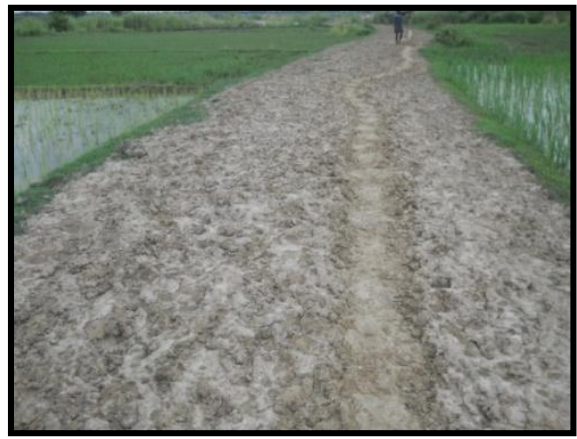

Figure 5

Figure 4 and 5: Damaged Roads at Haripur Village and Road within the Langolhata Beel during Post-Monsoon

\subsection{Impact of Excessive Use of Ground Water Irrigation}

The intense agricultural practice in and surrounding the beel area causes huge lowering of the ground water level due to overuse of ground water irrigation [11]. Therefore, the ground water irrigation is an environmental pressure factor which has been dramatically increasing since the last 50 years [12]. In the study 
area the introduction of HYV seeds and the use of chemical fertilizer have accelerated the use of ground water. The major source of irrigation in Labpur block is canal irrigation which covers about $64.14 \%$ of total irrigated area. Next to it is shallow tube well and submersible pump, which cover about $17.98 \%$ of total irrigated land. Wetlands have little contribution for irrigation because only the permanent beels like Kadpur, Belbuni, Surulia and some part of Langolhata beel can provide water for irrigation.

Table 5: Sources of Irrigation in Labpur Block

\begin{tabular}{|l|l|l|}
\hline Source of irrigation & Area in hectare & Area in \% \\
\hline Government canal & 12938 & 64.14 \\
\hline Tank & 1330 & 6.59 \\
\hline LDTW & 1700 & 8.42 \\
\hline STW/SMP & 3628 & 17.98 \\
\hline RLI & 450 & 2.23 \\
\hline Beel & 124 & 0.61 \\
\hline
\end{tabular}

. Source: Irrigation Office, 2013 LDTW: Low Capacity Deep Tubewell; STW: Shallow Tube Well RLI: River Lift Irrigation

Remarkable temporal changes have been noticed in irrigation pattern of this block. Data have been collected for Langolhata beel as case study. During 1981 the canal irrigated area of this beel was 556.84 hectare, pond and river irrigated area were of 380 and 535.25 hectare respectively (Fig.6). But after the introduction of HYV seeds and chemical fertilizer, the demand for large quantity of irrigated area has increased. Surface water sources like canal, pond and river cannot provide required amount of water. There are more than 250 submersible pumps within the beel region. This huge drafting of subsurface water causes the lowering down of ground water table at faster rate.

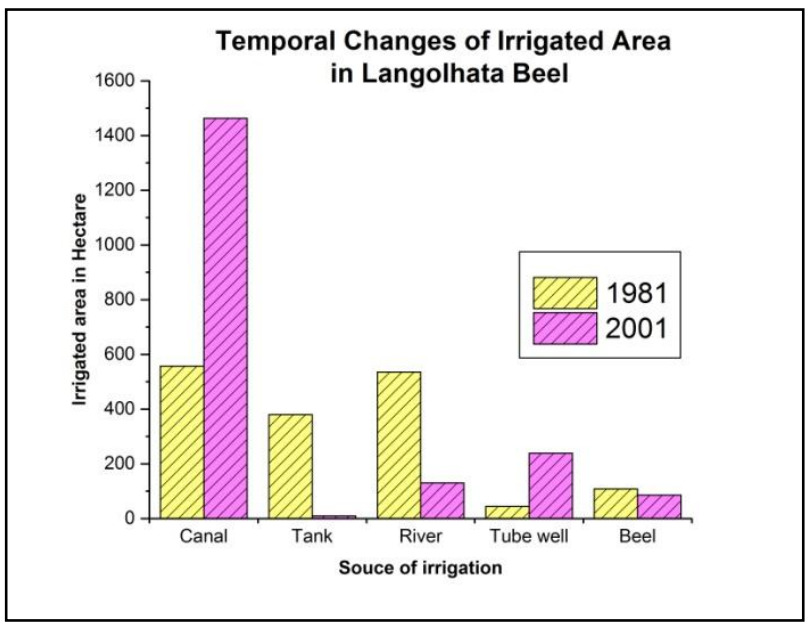

Figure 6

Table 6: Temporal Changes of Ground Water Status of Bee Areas

\begin{tabular}{|l|l|l|l|l|l|l|l|l|}
\hline Beel areas & \multicolumn{2}{|l|}{$\begin{array}{l}\text { Ground Water draft } \\
\text { in ham (2005-2006) }\end{array}$} & \multicolumn{2}{l|}{$\begin{array}{l}\text { Ground Water draft } \\
\text { in ham (2013-2014) }\end{array}$} & \multicolumn{2}{l|}{$\begin{array}{l}\text { Increase rate (\%) of } \\
\text { drafting }\end{array}$} & \multicolumn{2}{l|}{$\begin{array}{l}\text { Decline rate of } \\
\text { ground water } \\
\text { (2005-2014)mt }\end{array}$} \\
\cline { 2 - 9 } & $\begin{array}{l}\text { Pre } \\
\text { Monsoon }\end{array}$ & $\begin{array}{l}\text { Post } \\
\text { Monsoon }\end{array}$ & $\begin{array}{l}\text { Pre } \\
\text { Monsoon }\end{array}$ & $\begin{array}{l}\text { Post } \\
\text { Monsoon }\end{array}$ & $\begin{array}{l}\text { Pre } \\
\text { Monsoon }\end{array}$ & $\begin{array}{l}\text { Post } \\
\text { Monsoon }\end{array}$ & $\begin{array}{l}\text { Pre } \\
\text { Monsoon }\end{array}$ & $\begin{array}{l}\text { Post } \\
\text { Monsoon }\end{array}$ \\
\hline Langolhata & 4.63 & 2.29 & 5.54 & 3.03 & 19.78 & 32.50 & 2.54 & 2.02 \\
\hline $\begin{array}{l}\text { Laghata, } \\
\text { Kadpur }\end{array}$ & 2.41 & 1.71 & 3.18 & 2.63 & 31.85 & 53.75 & 5.00 & 2.72 \\
\hline Panchpara & 5.81 & 5.32 & 8.50 & 6.79 & 46.45 & 27.6 & 3.35 & 1.53 \\
\hline Laghosa, & 3.18 & 2.40 & 3.41 & 2.76 & 6.99 & 14.77 & 3.65 & 2.89 \\
\hline $\begin{array}{l}\text { Altore, } \\
\text { Patharghata }\end{array}$ & 2.15 & 1.69 & 2.67 & 2.35 & 24.1 & 38.92 & 4.96 & 4.58 \\
\hline
\end{tabular}

Data Source: Number and Yield Capacity of STW Collected from Electric Office, Labpur and Field Check 


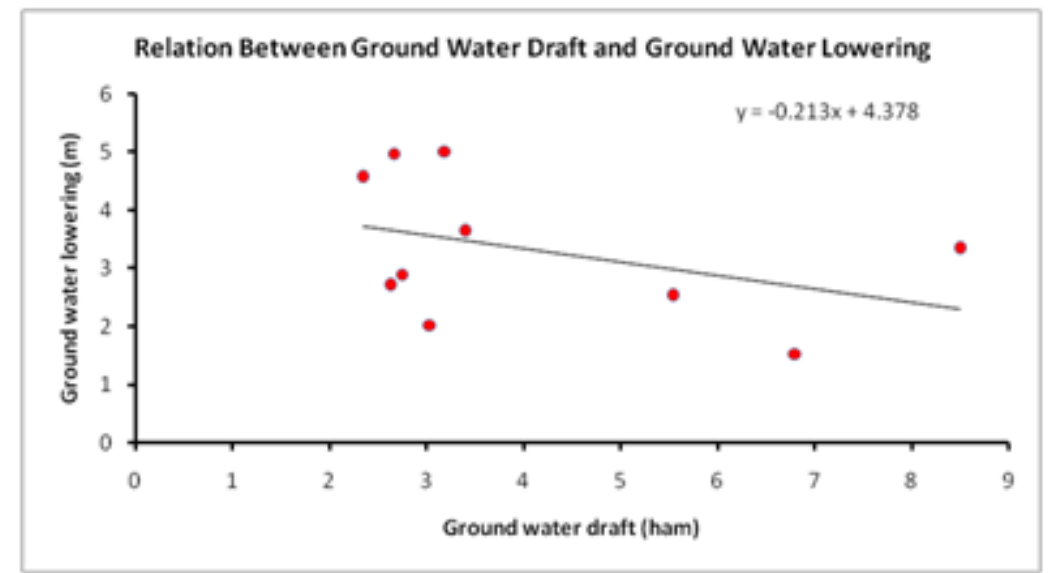

Figure 7

Table 6 reveals the temporal pattern of ground water drafting and consequent lowering down of the ground water level. It has also been observed that in every beel area ground water level is lowering down with the increasing of draft due to intensive irrigation. So, there is negative relationship between ground water draft and ground water lowering (Fig.7). The maximum ground water draft has been observed in the beel of Laghata, Kadpur, Langolhata, Altore and Panchpara where the lowering of ground water ranges between $2.5-5.0 \mathrm{mts}$ during last 8 years (Table 6; Fig. $8 \&$ 9). The rate of lowering down of the ground water level is an alarming phenomena in this region. The lowering down of ground water may be considered as the factor of decreasing tendency of soil moisture in the beel region as well as loss of wet character of the beel areas.

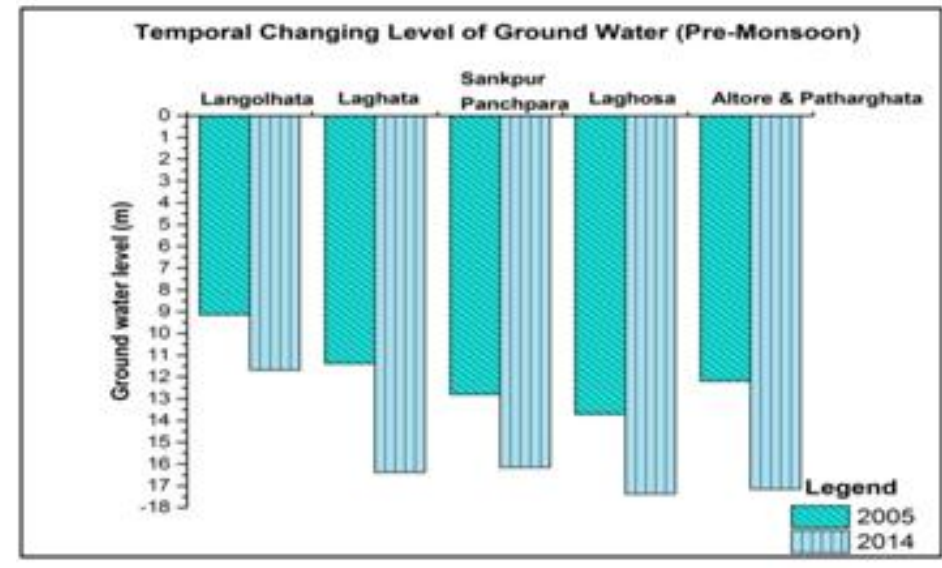

Figure 8

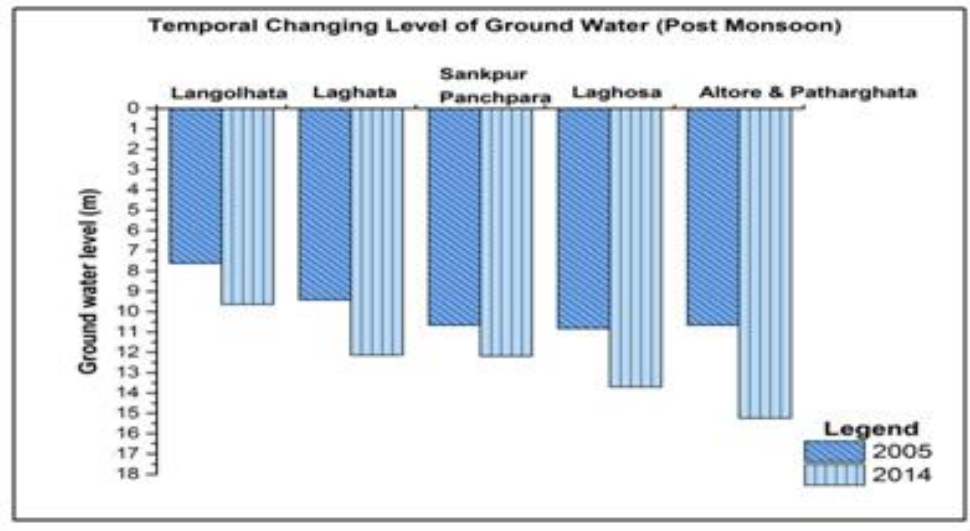

Figure 9

Source: CGWB, 2005 and Field Work 2014 


\subsection{Encroachment of Settlement}

About $6 \%$ of global land area is under the coverage of the wetlands. Scientists have noticed that both physical extension of the wetlands and their quality become degraded due to the residential extension over the past years [13]. In the study area wetlands are affected by the encroachment of settlement. Median center analysis of settlement distribution has been shown in Fig. 10. Here it is noticed that the median centers have the tendency toward the beel area. So, it is clear that with the extension of the agricultural land, the settlements are also encroaching towards centers of beels.

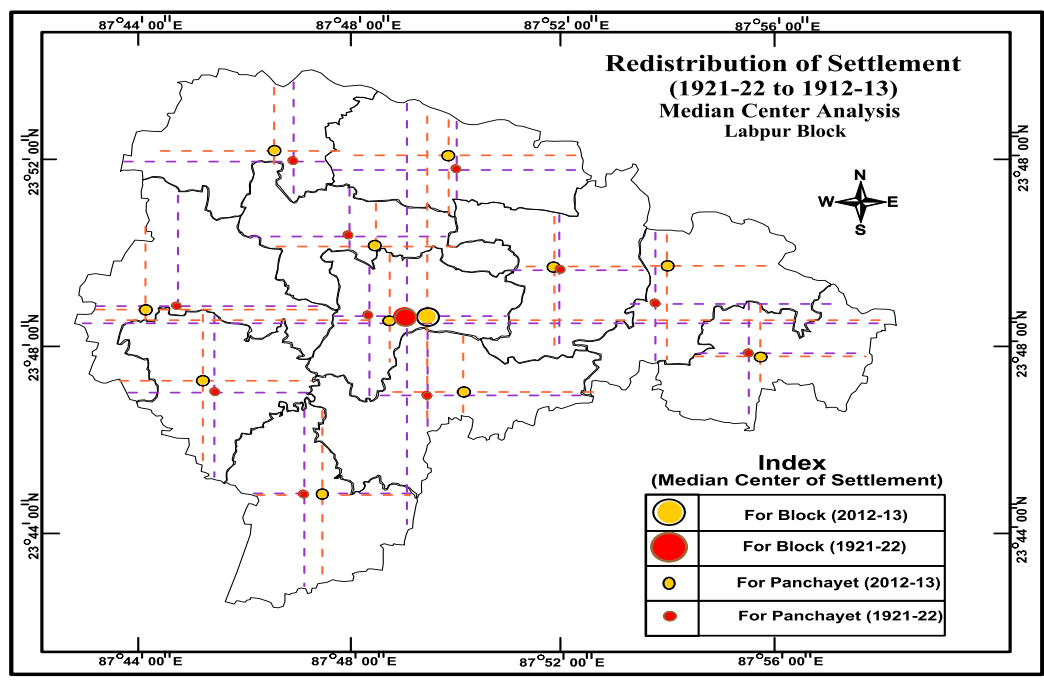

Data source: Toposheet SOI and Satellite Image

Figure 10: Shifting of Mean Center toward beel area

This encroachment disrupts the easy flow of flood water which intensifies the disaster of flood. Both direct and indirect anthropogenic activity led to shrinking of natural storage capacity in the catchment area, accelerating and intensifying the flood waves [9]. With the establishment of new roads, embankments, concrete houses are also being constructed to protect them from flood. All of these events create barrier against the free movement of the water of the wetlands and separate the wetlands from the river water. Fig 11 gives a pictorial view of settlement encroachment of the Lanoglhata beel. In this beel area 13 villages are fully or partially invading and day by day the settlements are being extended towards the beel area.

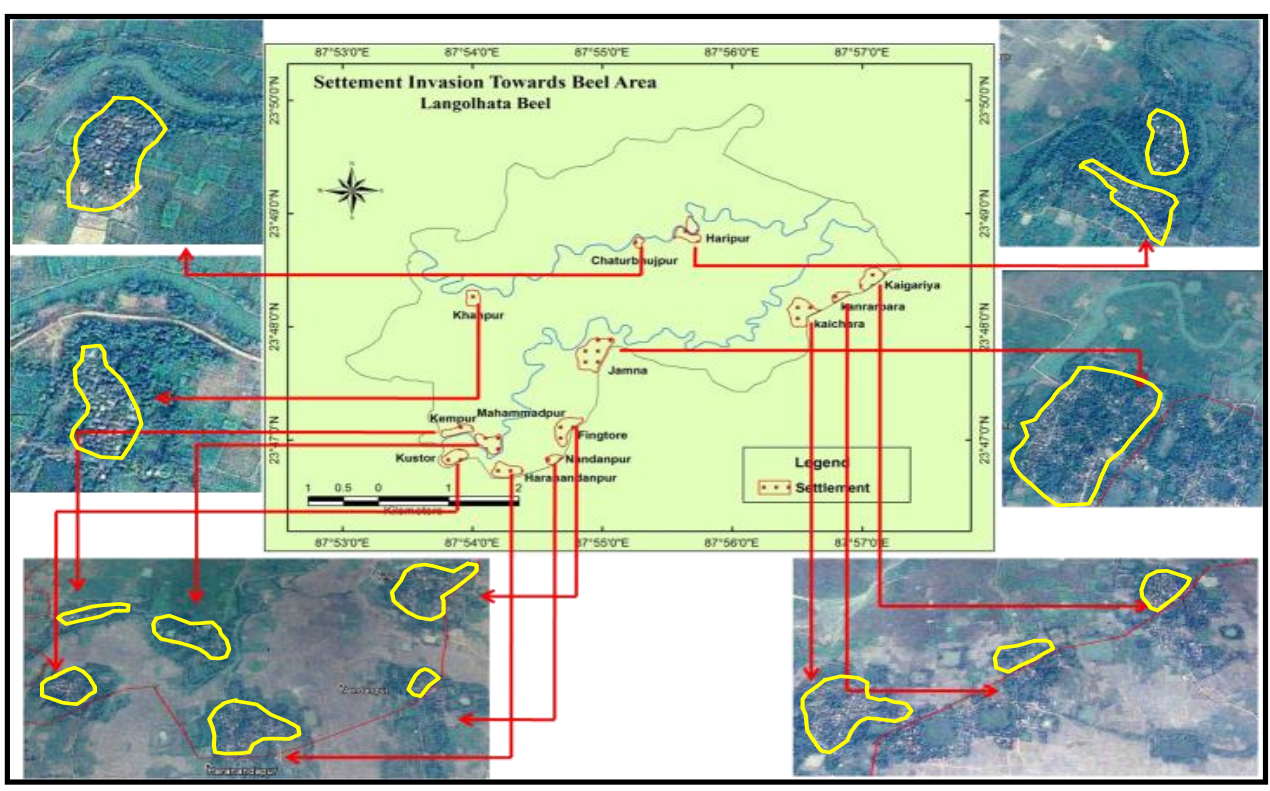

Source: Google Earth, 2015

Figure 11: Encroachment of Settlement toward beel area 


\subsection{Effect of Mini Barrage Construction}

Regulation of river by construction of barrage changes the hydrological behaviour of the wetlands. In Labpur block construction of Khanpur barrage and Mirity barrage on Kuya river affect the wetland character of the Langolhata beel. During pre-mosoon season both of these mini barrages restrict the flow of the rivers towards the beel. This stored water behind the barrage is used for irrigation. As a result major portion of this beel area remains dry (Fig. $13 \& 14$ ) due to high rate of evaporation (Avg. $85.13 \mathrm{~mm}$ in a year) and the wetting character of the hydric soil has been lost.

On the other hand, huge depositions occur behind the barrage. During monsoon, after crossing the threshold of water holding capacity of the barrages, huge discharge flow towards beel area washing those sediments which accelerates the rate of siltation. It is estimated that the rate is $0.3 \mathrm{~mm} /$ year during last five years. Consequently massive flood occurs every year overflowing the beel.

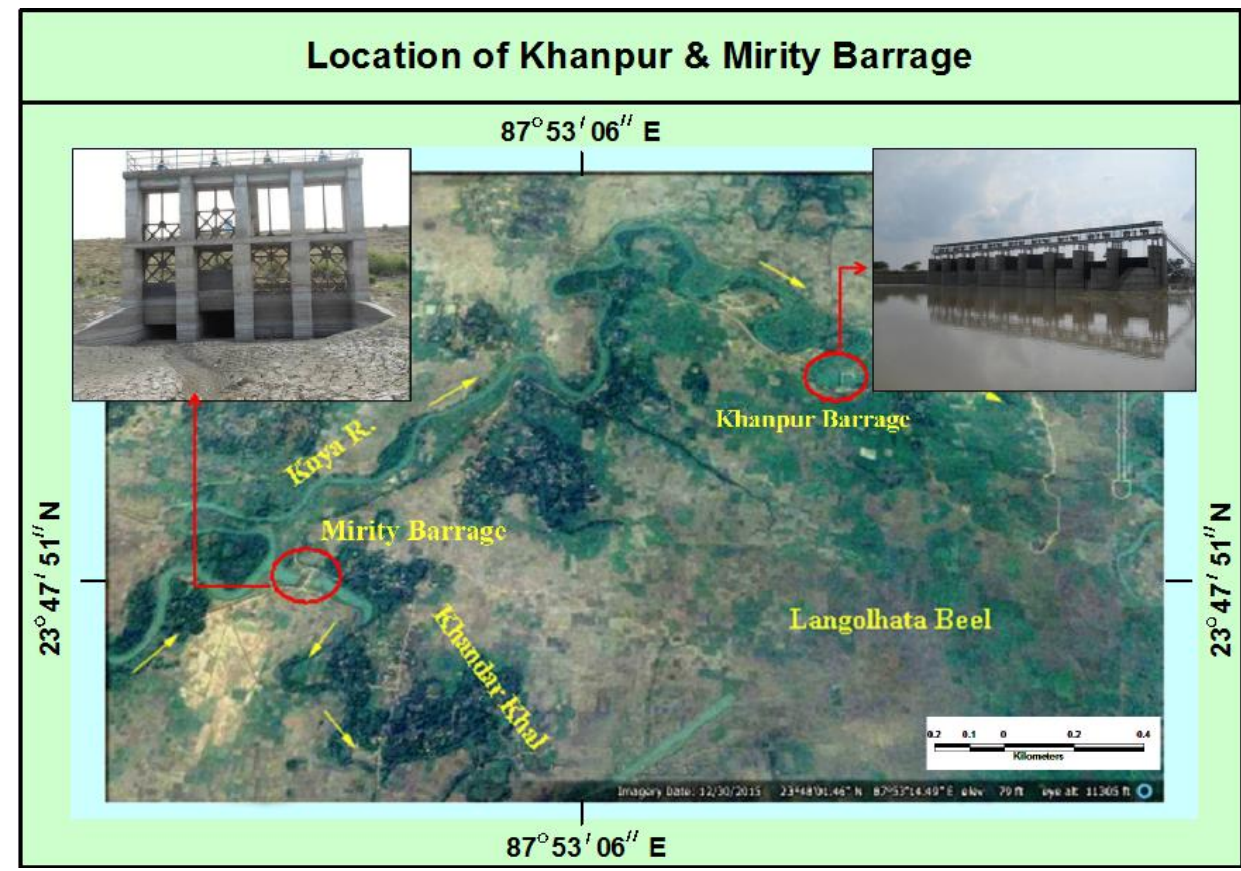

Source: Google Earth, 2015

Figure 12

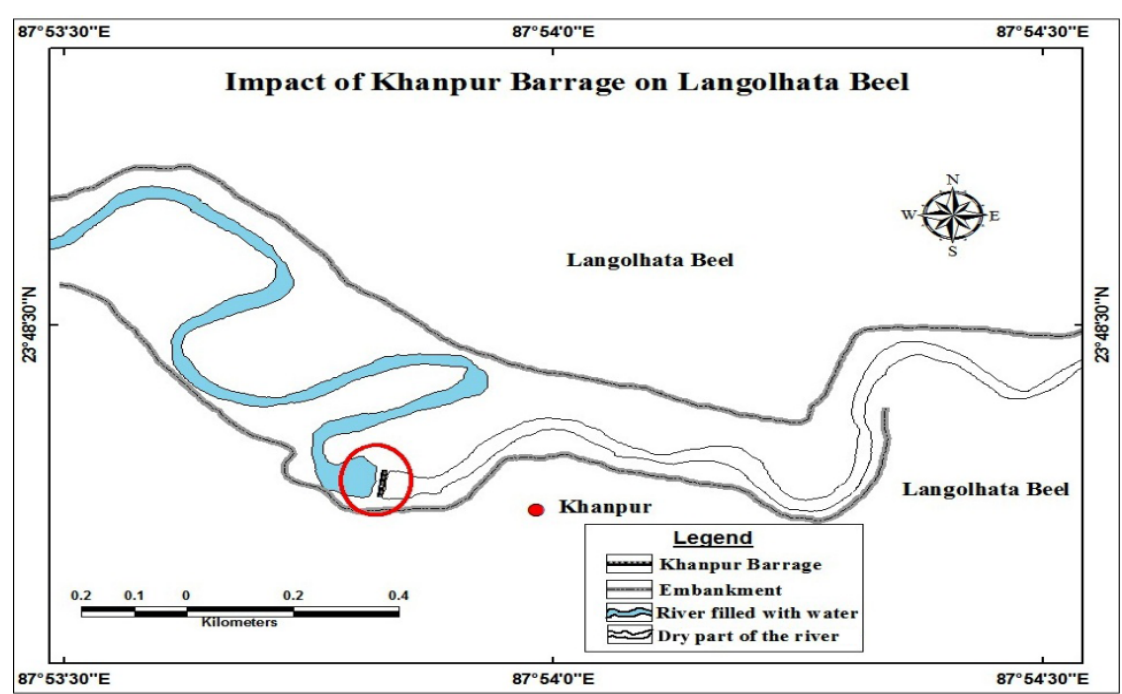

Source: Google Earth, 2015

Figure 13: Drying up of Kuya river after Khanpur Barrage 


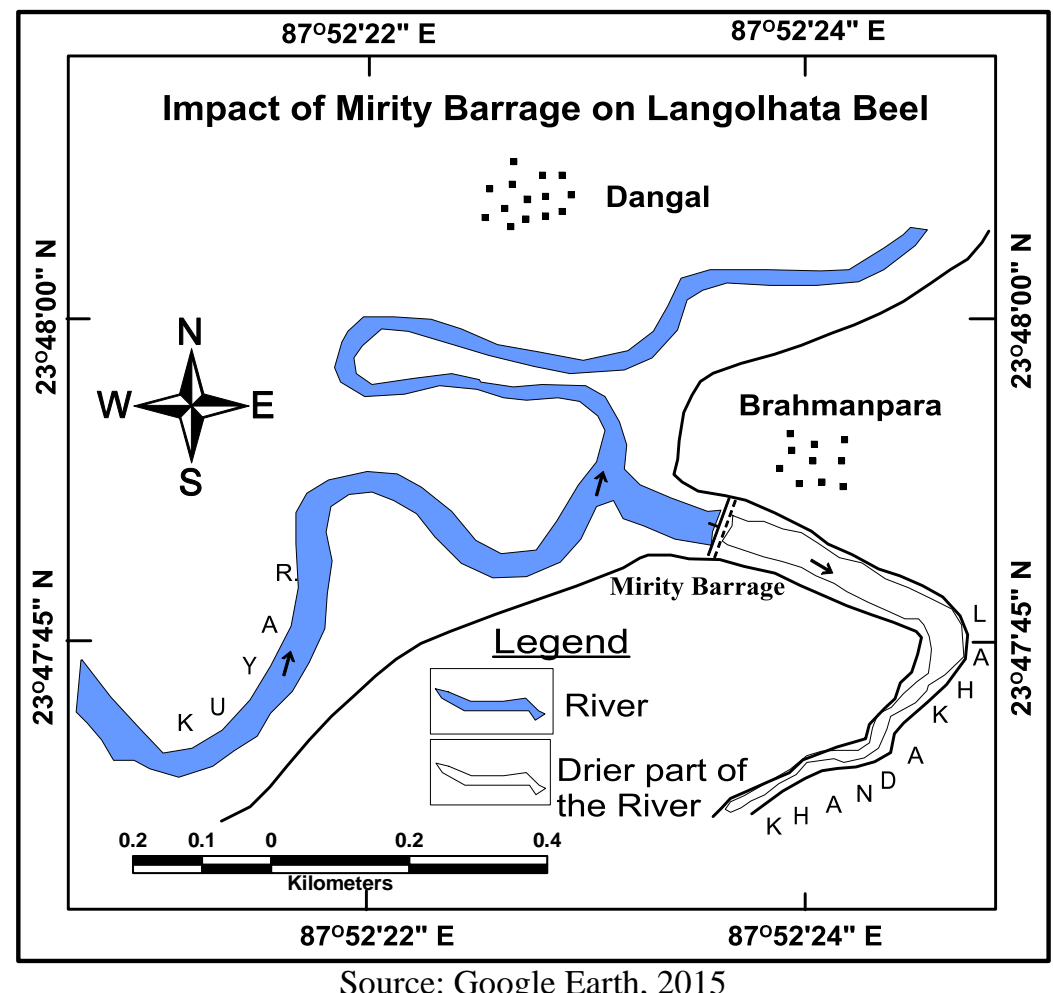

Figure 14: Drying up of Kuya river after Khanpur Barrage

\subsection{Some Proposed Remedial Measures}

The major manmade interventions toward wetlands are the construction of embankment and mini barrage, extension of roads through the beel area, expansion of settlement and agricultural field, excessive drafting of ground water etc. On the basis of collected data, map and field verifications, it is proved that all the above factors are responsible for the modification of hydrological character of the wetlands, such as the drying up of the portions, shrinkage in area, reduction of depth, loss of hydric character of soil and vegetation etc. Therefore, to protect the wetlands from the future deterioration a three-tier managerial programme has been formulated, i.e., wetland planning, design and management [14]. In this section some remedial measures regarding the restoration of wetlands may be accepted

a. Alternative livelihood may be accepted rather than the present economic use of wetland as paddy cultivation, i.e., if we use wetland as a fishing ground and extended lotus cultivation field though the conservation of its water, it will be a fruitful economic activity to the wetland dwellers.

b. The attitude of farmers should be altered in such a way that they would get interest to the economic activities other than paddy cultivation.

c. Active participation of local community, NGOs and Block Development authorities at all level of planning is necessary. Moreover the monitoring of the implementing measures is also necessary to meet the set goals.

d. Wetland requires an integrated research to maintain the stability between nature and man and formulation of long term conservation strategies [15]. So, multidisciplinary trained professionals are needed to train the local community about the importance of the wetlands for the development of their present and future economic status. Setting up of co-operative society should also be necessary for maintaining the marketing facilities of the end products.

e. Conduction of regular water quality monitoring by government and non-government agencies is required for maintaining the balance between hydrological character and biological habitat.

\section{CONCLUSION}

In the present day context, Man-Nature relationship is facing an awful situation due to dominancy of Man over Nature. In this point of view, wetlands as natural resource are under the grip of the economic man. Swelling up of water during monsoon season, concentration of major rivers and their tributaries are the common and natural phenomena of the floodplain wetlands, but it seems to be inflicting problems to the wetland dwellers. There is a vivid gap between perception of wetland dwellers about the wetlands and the importance of 
the wetlands. This gap is the result of ignorance of socio-economic evaluation of wetlands. Intervention of human being in different means towards the wetlands such as settlement encroachment, regulation of river by embankment, dams and barrages as well as with mini barrages, wetlands are on the edge of destruction and it may result in the conversion of wetland into 'land' and this change will not be fair for the human being.

So, implementation of planning is not enough to protect wetlands but it needs long term sustenance, abridgement between human and natural optimality. Some strict laws and regulations should be imperatively implemented by government officials as precaution and, if necessary, in punitive fashion.Each and every part of the world have the potentialities regarding the natural and economic parameters. At the mean time Nature also sets some deterministic rules which must be obeyed by man: that means the natural rules control the behaviour of the human being as well as their culture. But in the age of technological revolution man as a master of possibilism underestimates Nature and her natural rules which may cause inverse impact of the natural rules. So, there should be bridging the gap between Man and Nature. In this regard man should play the role of "traffic controller' as given in the concept of 'Neo-determinism' where Man regulates the intensity of natural phenomena but does not interfere against the direction of nature.A new paradigmatic shift should be set forward by integrating wetland and its water resource management. It brings all the wetland dwellers, all communities, government and others under one roof to make a successful man-nature relationship by conserving wetlands and its hydro-ecological function. All these aspects could build a healthy and wealthy environment in this region.

\section{REFERENCES}

[1] Cowardin, L.M., Carter, Virginia, Golet, F.C. and La Roe, E.T., Classification of Wetlands and deepwater habitat of United States, US Fish and Wildfish Service Report FWS/ OBS-79/31, 1979, 131.

[2] Roy, M.B., Roy, P.K., Samal N.R., Mazumder, A., Socio-Economic Valuation of Wetland Based Occupations of Lower Gangatic Basin through Approach, Journal of Environment and Natural Resources Research, 2 (4), 2012, 30-44.

[3] Tracy, B., Stephen, P., Vauling urban wetlands: A review of non-market valuation studies, Wetlands, 24, 2004, 744-755.

[4] Office of Technology Assessment, Wetlands: Their use and regulation, Washington, D.C.: U.S. Congress, Office of Technology Assessment, OTA-O-206, 1984.

[5] United Nations Environmental Programme, "The Environment in the News", Wednesday 17 October, 2012, 2.

[6] Dyer, F.J., Assessing the hydrological changes to floodplain wetland inundation caused by river regulation, The Structure, Function and Management Implication of Fluvial Sedimentary System, Proceedings of an International Symposium held at Alice Spinger, Australia, 2002, 245-253.

[7] Acreman, M.C and Miller, F., Hydrological Impact Assessment of Wetlands, International Symposium on Ground Water Sustainability (ISGWAS), San Fernando De Henares (Madrid), 2002.

[8] Vanderpoorten, A. and Klein J.P., A Comparative Study of Hydrophyte flora from the Alpine Rhine to Middle Rhine, Application to the Conservation of Upper Rhine Aquatic Ecosystem. Biological Conservation 83, 1999, 269-278.

[9] Bandhopadhyay, J. and Mallik, B., Floods: A Looks from an Eco-Hydrological Viewpoint, in Mukhopadhyay, M. (Ed.) River Floods: A Socio technical Approach, Visva Bharati, 2008, 5-6.

[10] Sreejith, K.A., Human impact on Kuttanad wetland ecosystem, International Journal of Science, Environment and Technology, 2 (4), 2013, 679-690.

[11] Molden D (ed), Water for food, water for life: A comprehensive assessment of water management in agriculture. Earthscan, London and International Water Management Institute, Colombo, 2007.

[12] Llamas, R and Custodio, E. Intensive use of groundwater - challenges and opportunities. Balkema, Leiden, 2003.

[13] Turner, B.L.; Clark W.C; Kates , R.W; Richard, J.F; Mathews J.T and Mayer W.B. (Eds), The Earth as Transformed by Human Action, Cambridge University Press, New York, 1990, 713.

[14] Trepel M., Dall 'O', M, Dal Cin, L., De Wit, M., Opitz, S., Palmeri, L., Perrson J., Pieterse M., Timmerman, T., Giuseppe, B., Kluge, W., Erikjorgensen, S., Model for Wetland Planning, design and Management, Ecosys Bd.8, 2000, 93-137.

[15] Kiran R. and Ramachandra, T.V., Status of wetlands in Bangalore and its conservation aspects in ENVIS Journal of Human Settlement, 1999. 